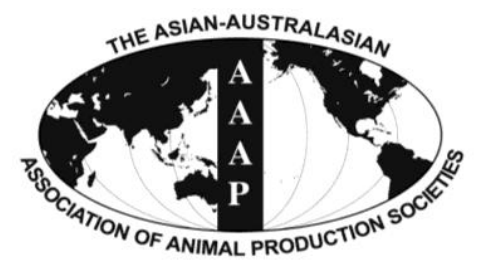

Asian-Aust. J. Anim. Sci.

Vol. 26, No. 2 : 218-226 February 2013

http://dx.doi.org/10.5713/ajas.2012.12504

www.ajas.info

pISSN 1011-2367 elSSN 1976-5517

\title{
Diets Based on Sugar Cane Treated with Calcium Oxide for Lambs
}

\author{
G. G. P. Carvalho ${ }^{1, *}$, R. Garcia ${ }^{2}$, A. J. V. Pires ${ }^{3}$, R. R. Silva ${ }^{3}$, E. Detmann ${ }^{2}$, \\ A. Eustaquio Filho ${ }^{1}$, L. S. O. Ribeiro ${ }^{3}$ and L. M. Carvalho ${ }^{2}$ \\ Southwest State University of Bahia, Itapetinga, BA, Brazil
}

\begin{abstract}
This experiment was conducted to evaluate the intake, nutrient apparent digestibility and the effect of total collection days (two and four days) on apparent digestibility estimates for lambs fed diets containing sugar cane treated with calcium oxide (CaO). Eight Santa Inês castrated male lambs with a $16.6 \pm 1.8 \mathrm{~kg}$ body weight were used. The lambs were distributed in two $4 \times 4$ Latin squares, with four experimental periods of $14 \mathrm{~d}$ each. The animals were kept in $1.2 \mathrm{~m}^{2}$ individual pens, and the intake and digestibility evaluations were performed during the last four days of each period. The diets were formulated to be isonitrogenous, containing $14 \%$ crude protein $(\mathrm{CP})$, and presenting $70 \%$ sugar cane treated with $0,0.75,1.5$ or $2.25 \%$ of $\mathrm{CaO}$ (as-fed basis), corrected with $1 \%$ urea, and $30 \%$ concentrate. The sugar cane with added $\mathrm{CaO}$ was chopped, treated, and offered to the animals after $24 \mathrm{~h}$ of storage. The sugar cane with $\mathrm{CaO}$ increased the DM, OM, CP, NDF, NDFap, TC, NFCap and TDN intake (kg/d), when compared to natural sugar cane, and produced the same intake expressed as a percentage of body weight $(\% \mathrm{BW})$. The NFCap digestibility of the CaO-treated sugar cane was inferior to the NFCap digestibility in natural sugar cane. There was a linear increase in the DM intake with the CaO-added sugar cane, but the DM and NDF digestibility and the TDN content decreased linearly. The chemical treatment of sugar cane with CaO increases the intake but does not improve the nutrient digestibility. Two days of total fecal collection were found to be sufficient to estimate the total apparent digestibility in lambs. (Key Words: Chemical Treatment, Dry Matter, Lime, Roughage)
\end{abstract}

\section{INTRODUCTION}

Lamb husbandry is a very important socioeconomic activity in northeast of Brazil (Costa et al., 2009). According to IBGE (2008), the Brazilian lamb flock in 2006 was estimated as $13,856,747$ animals, which $7,752,139$ were found in Brazil's northeastern. Housing the highest share of the Brazilian lamb herd (55.9\%), this region comprises a total area of 166.2 million hectare, of which 95.2 million (57\%) belong to the semi-arid zone, a region characterized by long periods of drought with highly seasonal forage production.

Within this context, sugar cane, a forage widely used in animal feeding, is a promising source to supply a lamb's nutrient needs during periods that the availability of forage

\footnotetext{
* Corresponding Author: G. G. P. Carvalho. Tel: +55-71-3283-6716, Fax: +55-71-3283-6718, E-mail: gleidsongiordano@yahoo.com.br ${ }^{1}$ Federal University of Bahia, Salvador - Bahia, 40170-110, Brazil.

${ }^{2}$ Federal University of Viçosa, Viçosa, MG, 36.570-000, Brazil.

${ }^{3}$ Southwest State University of Bahia, Itapetinga - Bahia, 45700000, Brazil.

Submitted Sept. 15, 2012; Accepted Oct. 29, 2012; Revised Nov. 18, 2012
}

with high quality is low because sugar cane is easily tillable, highly productive and its harvest time coincides with the period of forage shortage (Sousa et al., 2009; Pinto et al., 2010).

Despite the great productivity potential of some varieties, such as IAC 862480 that may reach more than 153 ton/ha (Landell et al., 2002), sugar cane has some nutritional limitations, including a low content of crude protein and high concentration of low digestible fiber (Pinto et al., 2009). The addition of urea to the sugar cane at the moment that is offered to the animals has been largely used to correct the protein deficiency. However, the negative effect of the low digestibility of the fibrous part has performed a challenge for the research field.

The low digestibility of the fiber reduces the passage rate, which directly reflects in a considerably decrease of the voluntary food intake (Prado and Moreira, 2002). Therefore, alternatives have been developed and proposed to increase the nutrient supply to the ruminal system, to improve the use of potentially digestible fiber, and to increase the passage rate of indigestible fiber.

The use of high amounts of concentrate in lamb diets has been an alternative when sugar cane serves as the only 
roughage in the ruminants' diets (Fernandes et al., 2009; Oliveira et al., 2009; Pessoa et al., 2009; Pinto et al., 2009). However, the elevated prices of this concentrates may increase the cost of the production system. Another option that has been greatly discussed lately is the addition of alkaline chemicals to the roughage treatment. For the latter, the focus has been to increase the nitrogen supply and to improve the digestibility of the fibrous portion of the food.

Several alkaline additives could potentially be used in the chemical treatment of roughage; urea and anhydrous ammonia are the most common ones (Souza et al., 2002). Among the benefits that those products can promote, several authors (Pires et al., 2004; Carvalho et al., 2006) have observed an increase in nitrogen in the treated material. The use of sodium hydroxide and calcium oxide do not contribute to the nitrogen supply, but these additives can increase the hydrolysis of the cell walls in roughage, improving the fiber digestibility and therefore the intake (Andrade et al., 2001; Oliveira et al., 2002; Oliveira et al., 2007).

Studies on ruminant nutrition have often searched for practical solutions to diminish the experimental work. The total fecal collection, an indispensable and necessary practice in some experiments involving feedlot animals to obtain the dry matter of the fecal excretion and estimate the nutrient digestibility, usually demands a great amount of manual labor for the collection activities, which are done during continuous $24 \mathrm{~h}$ periods. Methods using shorter periods of total collection but still leading to reliable estimates of the fecal excretion and digestibility are important to increase the practicability of these evaluations and to decrease the experimental labor.

The present study was conducted to evaluate the intake, the apparent nutrient digestibility and the effect of the number of days of total collection on the apparent digestibility estimates for lambs fed diets containing sugar cane treated with calcium oxide.

\section{MATERIAL AND METHODS}

\section{Experimental materials and procedures}

The experiment was conducted in the Lamb Husbandry Sector and the Forage and Pasture Laboratory of Southwest State University of Bahia, at Itapetinga campus, BA, Brazil. Eight Santa Inês castrated male lambs were used. Their initial mean body weight was $16.6 \pm 1.8 \mathrm{~kg}$, and they were three months old. The animals were distributed into two $4 \times 4$ Latin squares.

The lambs were kept in $1.2 \mathrm{~m}^{2}$ individual pens with wood-battened floors and were provided with feeders and water dispensers in the front of each pen. They were fed diets containing $70 \%$ sugar cane variety of RB72454 a third cut, treated with calcium oxide $(\mathrm{CaO})$ doses of $0,0.75,1.5$
Table 1. The percentage composition of concentrate and diet ingredients (\% of DM)

\begin{tabular}{lcc}
\hline Ingredient & Concentrate & Diet \\
\hline Sugar cane $^{1}$ & - & 70.0 \\
Corn meal & 55.7 & 16.8 \\
Soybean meal & 36.2 & 10.9 \\
Dicalcium phosphate & 2.3 & 0.7 \\
Mineral mixture & 5.8 & 1.6 \\
\hline
\end{tabular}

${ }^{1}$ Sugar cane with different calcium oxide doses.

and $2.25 \%$ concentrate and $30 \%$ (Table 1) based on dry matter. The natural sugar cane, with no treatment $(0 \%$ of $\mathrm{CaO}$ ) was chopped and offered to the animals at feeding time. The sugar cane treated with the $\mathrm{CaO}$ doses was chopped, weighed, treated with $\mathrm{CaO}$, stored in $50 \mathrm{~L}$ plastic buckets, and offered to the animals after $24 \mathrm{~h}$ of storage. During the entire period of the treatment $(24 \mathrm{~h})$ of the sugar cane, the temperature was monitored, as can be seen in Figure 1.

The sugar cane, in all treatments, was corrected by adding $1 \%$ urea, on an as-fed basis, at feeding time. The diets were calculated to provide enough nutrients to achieve a weight gain of $0.2 \mathrm{~kg} / \mathrm{d}$ (NRC, 2006). The diets were balanced to contain approximately $14 \%$ crude protein (CP), and the urea was added to the sugar cane by diluting it in water, with the amount of water calculated daily to obtain the ratio of $1 \mathrm{~kg}$ of urea to $4 \mathrm{~L}$ of water.

The chemical composition of the natural sugar cane with no urea added, of the sugar cane without treatment $(0 \%$ of $\mathrm{CaO})$, of the sugar cane treated with the $\mathrm{CaO}$ doses and corrected with $1 \%$ urea, and of the concentrate is provided in Table 2. Throughout the experiment, before the diets were offered to the animals, the soluble sugar content ( ${ }^{\circ}$ Brix) of the $\mathrm{CaO}$-treated and natural sugar cane was monitored, using a refractometer.

The $\mathrm{CaO}$ doses added to the sugar cane were measured using an as-fed basis without prior dilution in water. According to Moraes (2006), there is no need to dissolve

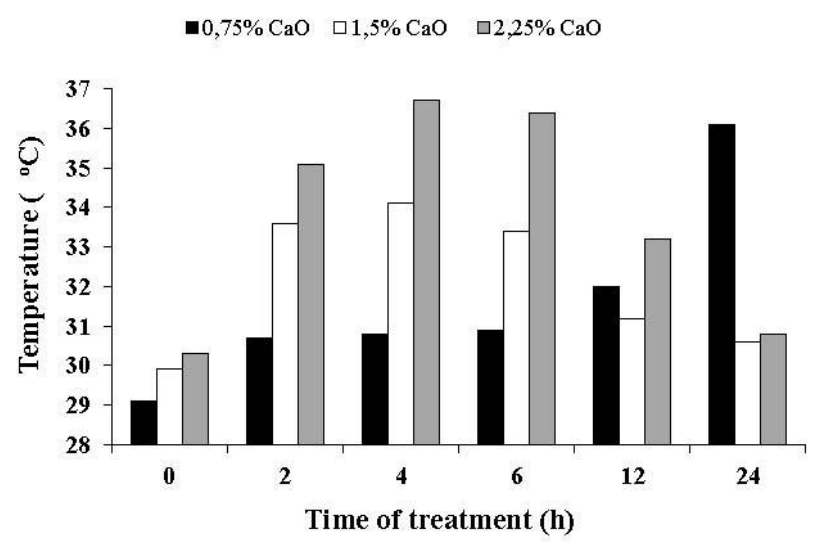

Figure 1. The mean temperature $\left({ }^{\circ} \mathrm{C}\right)$ of sugar cane treated with calcium oxide $(\mathrm{CaO}$, as-fed \%) during $24 \mathrm{~h}$ of treatment. 
Table 2. Average contents of dry matter, nutrients and $\mathrm{pH}$ values in the cane sugar in nature, cane sugar treated with different doses of calcium oxide $(\mathrm{CaO})$, and concentrated

\begin{tabular}{|c|c|c|c|c|c|c|}
\hline \multirow{2}{*}{ Item } & \multirow{2}{*}{ Natural sugar cane } & \multicolumn{4}{|c|}{$\mathrm{CaO}$ doses on sugar cane $\mathrm{e}^{1}$} & \multirow{2}{*}{ Concentrate } \\
\hline & & 0 & 0.75 & 1.5 & 2.25 & \\
\hline $\mathrm{DM}^{6}$ & 30.1 & 28.8 & 29.1 & 30.2 & 31.5 & 85.7 \\
\hline $\mathrm{OM}^{2,7}$ & 96.8 & 96.7 & 94.4 & 92.3 & 90.4 & 90.0 \\
\hline $\mathrm{CP}^{2,8}$ & 3.3 & 11.9 & 11.5 & 11.4 & 11.4 & 23.3 \\
\hline $\mathrm{NDIP}^{3,9}$ & 32.8 & 12.6 & 11.0 & 10.6 & 14.8 & 12.3 \\
\hline $\mathrm{ADIP}^{3,10}$ & 14.3 & 5.2 & 7.5 & 4.4 & 5.8 & 4.3 \\
\hline $\mathrm{EE}^{2,11}$ & 1.4 & 1.9 & 2.1 & 1.5 & 1.4 & 3.5 \\
\hline $\mathrm{Ash}^{2}$ & 3.2 & 3.3 & 5.6 & 7.7 & 9.6 & 10.0 \\
\hline $\mathrm{TC}^{2,12}$ & 92.1 & 82.2 & 80.8 & 79.3 & 77.6 & 63.3 \\
\hline $\mathrm{NDF}^{2,13}$ & 54.4 & 53.6 & 55.4 & 51.4 & 47.7 & 20.7 \\
\hline NDFap $^{2,14}$ & 52.0 & 51.2 & 53.3 & 48.7 & 44.9 & 12.3 \\
\hline $\mathrm{iNDF}^{2,15}$ & 32.2 & 31.3 & 32.2 & 27.6 & 23.2 & 1.8 \\
\hline $\mathrm{NDFpD}^{16}$ & 22.1 & 22.3 & 23.2 & 23.8 & 24.5 & 18.9 \\
\hline $\mathrm{NFC}^{2,17}$ & 37.7 & 28.6 & 25.4 & 27.9 & 29.8 & 38.6 \\
\hline NFCap $^{2,18}$ & 40.2 & 31.1 & 27.6 & 30.6 & 32.7 & 46.9 \\
\hline $\mathrm{ADF}^{2,19}$ & 36.8 & 36.2 & 38.0 & 33.5 & 33.0 & 10.2 \\
\hline $\mathrm{iADF}^{2,20}$ & 27.4 & 25.5 & 25.0 & 24.5 & 18.1 & 1.0 \\
\hline Hemicellulose $^{2}$ & 17.6 & 17.4 & 17.4 & 17.9 & 14.7 & 10.5 \\
\hline Cellulose $^{2}$ & 29.2 & 29.6 & 30.2 & 26.7 & 26.5 & 10.8 \\
\hline Lignin $^{2}$ & 6.6 & 7.2 & 7.1 & 6.1 & 5.6 & 1.1 \\
\hline $\mathrm{DMpD}^{2,21}$ & 69.6 & 70.7 & 69.8 & 74.2 & 78.5 & 97.6 \\
\hline $\mathrm{iDM}^{2,22}$ & 35.6 & 34.3 & 35.9 & 30.6 & 26.1 & 4.5 \\
\hline $\mathrm{TDN}^{2,4,23}$ & 61.3 & 60.4 & 58.2 & 58.7 & 58.4 & 73.2 \\
\hline${ }^{\circ}$ Brix $^{24}$ & 21.4 & 20.6 & 19.4 & 19.7 & 20.2 & - \\
\hline $\mathrm{pH}^{5}$ & 5.5 & 5.5 & 7.3 & 9.3 & 11.2 & - \\
\hline
\end{tabular}

${ }^{1}$ Sugar cane with $1 \%$ urea added, and $\mathrm{CaO}$ doses in as-fed percentage. ${ }^{2}$ Values in percentages of the DM. ${ }^{3}$ Values in percentages of the CP.

${ }^{4}$ Estimated according to NRC (2001). ${ }^{5}$ Obtained in sugar cane before the addition of $1 \%$ urea. ${ }^{6}$ Dry matter. ${ }^{7}$ Organic matter. ${ }^{8}$ Crude protein.

${ }^{9}$ Neutral detergent insoluble protein. ${ }^{10}$ Acid detergent insoluble protein. ${ }^{11}$ Ether extract. ${ }^{12}$ Total carbohydrate. ${ }^{13}$ Neutral detergent fiber.

${ }^{14}$ Neutral detergent fiber with corrections for ash and protein. ${ }^{15}$ Indigestible neutral detergent fiber. ${ }^{16}$ Potentially digestible neutral detergent fiber.

${ }^{17}$ Non-fibrous carbohydrate. ${ }^{18}$ Non-fibrous carbohydrate with corrections for ash and protein. ${ }^{19}$ Acid detergent fiber. ${ }^{20}$ Indigestible acid detergent fiber.

${ }^{21}$ Potentially digestible dry matter. ${ }^{22}$ Indigestible dry matter. ${ }^{23}$ Total digestible nutrients. ${ }^{24}$ Soluble sugar.

the lime in water because the sugar cane has enough water content to hydrate the $\mathrm{CaO}$. According to this author, only $1.0 \mathrm{~mol}$ of $\mathrm{H}_{2} \mathrm{O}$ for each mol of $\mathrm{CaO}$ is needed to form calcium hydroxide, $\mathrm{Ca}(\mathrm{OH})_{2}$, which means that $18.0 \mathrm{~g}$ of water is needed for each $56.0 \mathrm{~g}$ of lime.

The experiment was $56 \mathrm{~d}$ long and consisted of four experimental periods of $14 \mathrm{~d}$ each; the first ten days were designated for the animals' adaptation, and the final four days were designated for data collection.

The diets were offered ad libitum, twice a day, at 7 am and $3 \mathrm{pm}$, and they were adjusted to maintain 5 to $10 \%$ in leftovers from the amount offered. During the collection period, from the 11th to the 14th day of each experimental period, roughage, concentrate and leftover samples from each animal were collected daily, packed in plastic bags and stored in a freezer. The animals were weighed at the beginning and end of each experimental period.

For the quantification and evaluation of the voluntary intake, we used the feed provided between the 10th and the 13th day of each experimental period and the leftovers from the 11 th to the 14 th day.

Roughage, concentrate and leftover samples from each animal were dried in an oven with forced air circulation $\left(60^{\circ} \mathrm{C}\right)$ and processed in a knife mill $(1 \mathrm{~mm})$. The dry matter $(\mathrm{DM})$, organic matter $(\mathrm{OM})$, crude protein $(\mathrm{CP})$, ether extract (EE), neutral detergent fiber (NDF), acid detergent fiber (ADF), neutral detergent insoluble protein (NDIP), acid detergent insoluble protein (ADIP), cellulose, hemicelluloses and lignin $\left(\mathrm{H}_{2} \mathrm{SO}_{4} 72 \% \mathrm{w} / \mathrm{w}\right)$ contents were determined according to the procedure described by Silva and Queiroz (2002). The neutral detergent fiber content with corrections for ash and protein (NDFap) was determined according to the recommendations of Licitra et al. (1996) and Mertens (2002).

The estimates of the feed's potentially digestible neutral detergent fiber (NDFpD) and potentially digestible dry matter (DMpD) were determined according to NRC (2001).

The total carbohydrate (TC) content was estimated according to Sniffen et al. (1992) as: TC $=100-(\% \mathrm{CP}+\%$ $\mathrm{EE}+\%$ ash). 
The non-fibrous carbohydrate, with corrections for ash and protein (NFCap) content, was calculated with an adapted equation of the one proposed by Hall (2003): NFCap $=(100-\%$ NDFap-\% CP-\% EE-\% ash $)$.

The total digestible nutrients (TDN) were calculated according to Weiss (1999) but using the NDF and the NFC with corrections for ash and protein, using the following equation:

\section{TDN $(\%)=$ DCP+NDFapD+NFCapD+2.25 DEE}

Where: $\mathrm{DCP}=$ digestible $\mathrm{CP}$; NDFapD = digestible NDFap; NFCapD = digestible NFCap; and $\mathrm{DEE}=$ digestible EE.

The estimated total digestible nutrients (TDNest) of the raw materials and the total diets were calculated according to the equations described by NRC (2001). For the TDNest calculation of the sugar cane, the following equation was used:

$$
\begin{aligned}
\text { TDNest }= & 0.98(100-(\% \mathrm{NDFp}+\% \mathrm{CP}+\% \mathrm{EE}+\% \text { ash })) \\
& \times \mathrm{FP}+\mathrm{CP} \times \exp (-1.2 \times(\mathrm{ADIP} / \mathrm{CP}))+2.25 \\
& \times(\mathrm{EE}-1)+0.75 \times(\mathrm{NDFp}-\text { Lignin }) \\
& \times\left(1-(\text { Lignin } / \mathrm{NDFp})^{0.667}\right)-7
\end{aligned}
$$

For the calculation of the TDNest of the concentrate diets, the following equation was used:

$$
\begin{aligned}
\text { TDNest }= & 0.98(100-(\% \mathrm{NDFp}+\% \mathrm{CP}+\% \mathrm{EE}+\% \text { ash })) \\
& \times \mathrm{FP}+\mathrm{CP} \times \exp (-0.4 \times(\mathrm{ADIP} / \mathrm{CP}))+2.25 \\
& \times(\mathrm{EE}-1)+0.75 \times(\mathrm{NDFp}-\text { lignin }) \\
& \times\left(1-(\text { lignin } / \mathrm{NDFp})^{0.667}\right)-7
\end{aligned}
$$

where:

NDFp $=$ NDF-NDIP $($ NDIP $=$ neutral detergent insoluble nitrogen $\times 6.25$ );

$\mathrm{FP}=$ the physical processing effect on the digestibility of non-fibrous carbohydrate; and

ADIP $=$ acid detergent insoluble nitrogen $\times 6.25$

For $\mathrm{EE}<1$ values, on the equation, $(\mathrm{EE}-1)=0$

For the estimate of the apparent digestibility coefficient, the total animal fecal collection was performed from the 11 th to the 14th day of each experimental period. The collection in each period, per animal, was done using a polyethylene canvas, installed in the lower part of each pen. The total feces were weighed in the morning, and approximately $10 \%$ was removed and stored in a freezer at $-10^{\circ} \mathrm{C}$ for later analysis. From the daily samples, two composed feces samples were set apart for use in comparing the periods of collection. The first sample was composed of feces from the first two days of collection (11th and 12th), and the second sample was composed of feces from all four consecutive collection days (11th to 14 th).

For the estimates of indigestible dry matter (iDM) and indigestible neutral detergent fiber (iNDF) used to estimate the intake, samples of the provided feed (sugar cane and concentrate) and the leftovers were incubated for $240 \mathrm{~h}$ (Casali et al., 2008), in duplicate $\left(20 \mathrm{mg} \mathrm{DM} / \mathrm{cm}^{2}\right)$, in nonwoven tissue $\left(100 \mathrm{~g} / \mathrm{m}^{2}\right)$ bags, inserted in the rumen of two steers receiving a mixed diet. After this period, the bags were removed and washed with running water, and the remaining material from the incubation was dried in an oven with forced air circulation at $60^{\circ} \mathrm{C}$ for $72 \mathrm{~h}$. Next, they were removed from the oven, put in a desiccator and weighed; the residue obtained was considered to be the iDM. Next, the bags were put in plastic pots, and $50 \mathrm{ml}$ of neutral detergent was added to each bag. The bags were boiled in neutral detergent for one hour, then washed with hot water and acetone, dried and weighed, as in the previous procedure; the new residue was considered to be the iNDF.

\section{Statistical analysis}

The comparison of the days of total collection for the fecal excretion and for the nutrient digestibility estimates was performed using a scheme of subdivided portions, where the portions were composed by the diets (with different $\mathrm{CaO}$ doses) and the sub-portions were the days of collection.

The intake, nutrient digestibility and TDN estimates were compared among treatments using the decomposition of squares sum related to the $\mathrm{CaO}$ doses in the sugar cane, by orthogonal contrasts, as described in Table 3.

To the first contrast (A), we attributed the comparison between the means of the control treatment (natural sugar cane) and the treatments involving the sugar cane treated with calcium oxide. The contrasts represented by letters $B$ and $\mathrm{C}$ allowed the evaluation of linear and quadratic order effects, respectively, as a function of the calcium oxide doses on the sugar cane. The statistical procedures were performed using the SAS (Statistical Analysis System) software, adopting 0.05 as the critical level of probability.

\section{RESULTS AND DISCUSSION}

The treatments using the sugar cane treated with $\mathrm{CaO}$

Table 3. The coefficient distribution for orthogonal contrasts used for decomposition of the square sum for the treatments

\begin{tabular}{lcccc}
\hline \multirow{2}{*}{ Contrast } & \multicolumn{4}{c}{ Coefficients } \\
\cline { 2 - 5 } & In natura sugar cane & 0.75 & 1.5 & 2.25 \\
\hline $\mathrm{A}$ & +3 & -1 & -1 & -1 \\
$\mathrm{~B}$ & 0 & -1 & 0 & +1 \\
$\mathrm{C}$ & 0 & -1 & +2 & -1 \\
\hline
\end{tabular}


showed a higher intake $(\mathrm{p}<0.01)$ of DM, OM, CP, NDF, NDFap, TC, NFCap and TDN $(\mathrm{kg} / \mathrm{d})$ when compared to the natural sugar cane treatment $(0 \% \mathrm{CaO})$ Similar results were found for the intake expressed as a percentage of the body weight $(\mathrm{BW})$, where the $\mathrm{CaO}$-treated sugar cane was superior to the control treatment (natural sugar cane), with a higher intake $(\mathrm{p}<0.01)$ of the DM, OM, NDF, NDFap and TDN (Table 4).

Using the other contrasts to detect the functional relationship between the addition of the $\mathrm{CaO}$ to the sugar cane and the response variables, we observed a linear increase in the DM $(\mathrm{p}<0.05)$ and the NFCap $(\mathrm{p}<0.01)$ intakes $(\mathrm{kg} / \mathrm{d})$ and the $\mathrm{DM}(\mathrm{p}<0.05)$ intake as a percentage of BW. We also recorded an increasing linear behavior for the DM $(\mathrm{p}<0.05)$ intake, expressed as $\mathrm{g} / \mathrm{kg}^{0.75}$. The iDM and iNDF intakes $(\mathrm{kg} / \mathrm{d})$, however, were negatively and linearly associated with the $\mathrm{CaO}$ doses added to the sugar cane.

The sugar cane treated with the $\mathrm{CaO}$ doses showed adequate chemical characteristics (Table 2) and apparently good palatability, which could explain the higher nutrient intake for the diets containing the $\mathrm{CaO}$-treated sugar cane. The increase in the observed DM intake is an achievement that has been sought in several studies using alkaline additives for the sugar cane treatment (Moraes, 2006; Amaral, 2007; Campos, 2007). However, using these chemical additives on roughage has not always promoted an increase in the nutrient intake in ruminant animals.

Moraes (2006), when offering natural sugar cane, treated or not treated with $1 \% \mathrm{CaO}(\% \mathrm{NM})$ for $24 \mathrm{~h}$, to crossbred heifers, noted a reduction in the nutrient intake in animals fed the $\mathrm{CaO}$-treated sugar cane. According to the author, the high temperature of the $\mathrm{CaO}$-added sugar cane, when compared to the natural sugar cane, may have been the factor responsible for the lower nutrient intake observed. In the present study, however, except for the sugar cane treated with $0.75 \%$ of $\mathrm{CaO}$, where it seems that fermentation occurred after $24 \mathrm{~h}$ of the treatment due to the temperature increase (Figure 1), the other treatments with $1.5 \%$ and $2.25 \%$ of $\mathrm{CaO}$ showed high temperatures in the first hours after the $\mathrm{CaO}$ addition, but after $24 \mathrm{~h}$, the values

Table 4. Least square means, coefficient of variation (CV) and descriptive levels of probability contrasts (p-value) of dry matter and nutrients in lambs fed diets containing natural sugar cane or sugar cane Treated with calcium oxide (CaO) doses of $0.75,1.5$ and $2.25 \%$ (as-fed basis)

\begin{tabular}{|c|c|c|c|c|c|c|c|c|}
\hline \multirow{2}{*}{ Item } & \multicolumn{4}{|c|}{ Treatments } & \multirow{2}{*}{ SD } & \multicolumn{3}{|c|}{ p-value ${ }^{1}$} \\
\hline & Natural sugar cane & 0.75 & 1.5 & 2.25 & & $\mathrm{C}$ vs. $\mathrm{CaO}$ & $\mathrm{L}$ & Q \\
\hline \multicolumn{9}{|l|}{ Intake $(\mathrm{kg} / \mathrm{d})$} \\
\hline $\mathrm{DM}^{2,9}$ & 0.637 & 0.709 & 0.765 & 0.776 & \pm 0.06 & 0.0002 & 0.0337 & 0.3785 \\
\hline $\mathrm{iDM}^{3,10}$ & 0.105 & 0.126 & 0.114 & 0.090 & \pm 0.03 & 0.4999 & 0.0015 & 0.4995 \\
\hline $\mathrm{OM}^{11}$ & 0.600 & 0.657 & 0.696 & 0.695 & \pm 0.05 & 0.0017 & 0.1705 & 0.4119 \\
\hline $\mathrm{CP}^{12}$ & 0.118 & 0.126 & 0.134 & 0.136 & \pm 0.01 & 0.0039 & 0.0703 & 0.4685 \\
\hline $\mathrm{EE}^{4,13}$ & 0.015 & 0.019 & 0.016 & 0.015 & \pm 0.00 & 0.2365 & 0.0050 & 0.4973 \\
\hline $\mathrm{NDF}^{14}$ & 0.247 & 0.289 & 0.296 & 0.284 & \pm 0.03 & 0.0021 & 0.7395 & 0.4569 \\
\hline NDFap $^{15}$ & 0.220 & 0.260 & 0.260 & 0.246 & \pm 0.03 & 0.0044 & 0.3022 & 0.5828 \\
\hline $\mathrm{iNDF}^{5,16}$ & 0.102 & 0.119 & 0.111 & 0.088 & \pm 0.02 & 0.6294 & 0.0024 & 0.3439 \\
\hline $\mathrm{TC}^{17}$ & 0.466 & 0.512 & 0.546 & 0.545 & \pm 0.04 & 0.0013 & 0.1462 & 0.3748 \\
\hline $\mathrm{NFCap}^{6,18}$ & 0.247 & 0.252 & 0.286 & 0.299 & \pm 0.02 & 0.0016 & 0.0003 & 0.2719 \\
\hline $\mathrm{TDN}^{19}$ & 0.431 & 0.476 & 0.494 & 0.495 & \pm 0.04 & 0.0062 & 0.3976 & 0.6586 \\
\hline \multicolumn{9}{|c|}{ Intake (\% of body weight) } \\
\hline $\mathrm{DM}^{7}$ & 3.39 & 3.64 & 3.94 & 3.99 & \pm 0.25 & 0.0002 & 0.0109 & 0.2494 \\
\hline $\mathrm{OM}$ & 3.19 & 3.37 & 3.59 & 3.58 & \pm 0.23 & 0.0039 & 0.0949 & 0.2807 \\
\hline NDF & 1.32 & 1.48 & 1.53 & 1.46 & \pm 0.13 & 0.0038 & 0.7426 & 0.3045 \\
\hline NDFap & 1.17 & 1.33 & 1.34 & 1.26 & \pm 0.11 & 0.0081 & 0.2318 & 0.4077 \\
\hline TDN & 2.30 & 2.44 & 2.54 & 2.55 & \pm 0.19 & 0.0131 & 0.2488 & 0.5509 \\
\hline \multicolumn{9}{|c|}{ Intake $\left(\mathrm{g} / \mathrm{kg}^{0.75}\right)$} \\
\hline $\mathrm{DM}^{8}$ & 70.42 & 76.29 & 82.61 & 83.68 & \pm 5.32 & 0.0001 & 0.0128 & 0.2710 \\
\hline \multicolumn{9}{|c|}{$\begin{array}{l}{ }^{1} \mathrm{C} \text { vs } \mathrm{CaO} \text { : control (natural sugar cane) vs sugar cane with calcium oxide }(\mathrm{CaO}) \text { added; } \mathrm{L} \text { and } \mathrm{Q} \text { : linear and quadratic effects for } \mathrm{CaO} \text { doses on suga } \\
\text { cane. }\end{array}$} \\
\hline \multicolumn{9}{|c|}{${ }^{2} \hat{Y}=0.682532+0.0447946 \mathrm{X}\left(\mathrm{r}^{2}=0.8672\right) .{ }^{3} \hat{Y}=0.146196-0.0239499 \mathrm{X}\left(\mathrm{r}^{2}=0.9672\right) .{ }^{4} \hat{Y}=0.0202923-0.00254223 \mathrm{X}\left(\mathrm{r}^{2}=0.9497\right)$} \\
\hline \multicolumn{9}{|c|}{${ }^{5} \hat{Y}=0.137230-0.0208223 \mathrm{X}\left(\mathrm{r}^{2}=0.9335\right) .{ }^{6} \hat{Y}=0.232067+0.0313977 \mathrm{X}\left(\mathrm{r}^{2}=0.9371\right) .{ }^{7} \hat{Y}=3.50389+0.234219 \mathrm{X}\left(\mathrm{r}^{2}=0.8507\right)$} \\
\hline \multicolumn{9}{|c|}{$\begin{array}{l}{ }^{8} \hat{Y}=73.4770+4.92180 \mathrm{X}\left(\mathrm{r}^{2}=0.8557\right) .{ }^{9} \text { Dry matter. }{ }^{10} \text { Indigestible dry matter. }{ }^{11} \text { Organic matter. }{ }^{12} \text { Crude protein. }{ }^{13} \text { Ether extract. } \\
{ }^{14} \text { Neutral detergent fiber. }{ }^{15} \text { Neutral detergent fiber with corrections for ash and protein. }{ }^{16} \text { Indigestible neutral detergent fiber. }{ }^{17} \text { Total carbohydrate. }\end{array}$} \\
\hline
\end{tabular}


reduced to nearly the environmental temperature (Figure 1).

The increase in the fiber intake in $\mathrm{kg} /$ day and $\%$ of body weight (contrast: $\mathrm{C}$ vs $\mathrm{CaO}$ ) due to the $\mathrm{CaO}$ addition to the sugar cane (Table 4) may be related to the possible benefits of the chemical treatment, which from this dose on, may have not shown an effect. In the study conducted by Pires et al. (2004), it was observed that higher DM and NDF intake in steers fed roughage treated with $4 \% \mathrm{NH}_{3}$ (\% DM) improved the animals' performance. According to the authors, the alterations in the fibrous portion of the treated material were essential to obtain those results.

Pontes (2007) evaluated the effect of diets containing sugar cane treated with three $\mathrm{CaO}$ doses $(0,0.5$ and $1 \%$, asfed $\%)$ and two different storage times ( 0 and $24 \mathrm{~h})$ and did not observe any effect from these treatments on the DM, $\mathrm{OM}, \mathrm{CP}$, NDF, NFC and TDN intakes, in $\mathrm{kg} / \mathrm{d}$, in lambs. From the results obtained in the present study and the ones reported in the literature previously cited, it can be observed that the addition of $\mathrm{CaO}$ to sugar cane may or may not promote an increase in nutrient intake. The negative effects of this additive on those variables are contrary to the assumptions of improved digestibility and voluntary intake and are still poorly understood.

The DM intake (\% BW), as shown in Table 4, increased linearly $(\mathrm{p}<0.01)$, with the estimated values of $3.67,3.85$ and $4.03 \%$ for $0.75,1.5$ and $2.25 \%$ doses of $\mathrm{CaO}$, respectively. This increase corresponded to a 8.3, 13.6 and $18.9 \%$ increase in the $\mathrm{DM}$ and in $\% \mathrm{BW}$ for the diets containing sugar cane treated with $0.75,1.5$ and $2.25 \%$ of $\mathrm{CaO}$, respectively, when compared to the diet containing natural sugar cane. The possible beneficial effects of the $\mathrm{CaO}$ chemical treatment of sugar cane may have promoted an increase in the feed passage rate, leading to an increased intake, which explains the results with these treatments.
As for digestibility, analyzing the contrasts of natural sugar cane vs. $\mathrm{CaO}$-treated sugar cane $(\mathrm{C}$ vs $\mathrm{CaO})$, it was observed that the treatments containing $\mathrm{CaO}$-treated sugar cane lowered the DM and NFCap digestibility. The other components did not show any significant effect $(p>0.05)$. The DM and NDF digestibility coefficients and the TDN content coefficient were linear and negatively associated ( $p>0.05$ ) for the $\mathrm{CaO}$ doses added to the sugar cane (Table 5). The decrease in DM digestibility observed in the diets containing $\mathrm{CaO}$-treated sugar cane disagrees with the assumptions presented by several authors (Pires et al., 2003; Cavali, 2006; Balieiro et al., 2007), who stated that alkaline treatment positively affects the DM digestibility. It is possible that the digestibility was influenced by the passage rate to obtain the elevated intake rates observed.

Different results were obtained by Cavali (2006), who evaluated $\mathrm{CaO}$ doses of $0,0.5,1.0,1.5$ and $2.0 \%$ (as-fed \%) added at the moment of sugar cane ensilage and observed an increase in in vitro dry matter digestibility (IVDMD). According to the results presented by the author, the IVDMD values were 48.4, 65.6, 74.9, 78.2 and $81.5 \%$, corresponding to increases of $35.5,54.8,61.6$ and $68.4 \%$ for the treatments of $0.5,1.0,1.5$ and $2.0 \%$, respectively, when compared to the control treatment $(0 \%)$ with no $\mathrm{CaO}$ addition. The IVDMD increase was also reported by Oliveira et al. (2007), who added $0,0.5$ and $1 \%$ doses of $\mathrm{CaO}$ (as-fed \%) to natural sugar cane and obtained values of $63.2,64.8$ and $65.6 \%$, respectively.

Usually, the results obtained in experiments conducted in vitro, as described here, diverge from the in vivo results. In most in vitro studies, the digestibility increases with diets of sugar cane treated with $\mathrm{CaO}$, while in trials using animals, the digestibility decreases or shows no effect with the addition of $\mathrm{CaO}$ to the sugar cane. In a study involving

Table 5. Least square means, coefficients of variation (CV) and descriptive levels of probability for contrasts (p-value) of the digestibility of dry matter and nutrients in lambs fed diets containing natural sugar cane or sugar cane treated with calcium oxide (CaO) doses of $0.75,1.5$ and $2.25 \%$ (as-fed basis)

\begin{tabular}{|c|c|c|c|c|c|c|c|c|}
\hline \multirow{2}{*}{ Item } & \multicolumn{4}{|c|}{ Treatments } & \multirow{2}{*}{ SD } & \multicolumn{3}{|c|}{ p-value $^{1}$} \\
\hline & Natural sugar cane & 0.75 & 1.5 & 2.25 & & $\mathrm{C}$ vs $\mathrm{CaO}$ & $\mathrm{L}$ & Q \\
\hline $\mathrm{DM}^{2,5}$ & 68.0 & 67.3 & 65.9 & 65.1 & \pm 1.7 & 0.0100 & 0.0146 & 0.7009 \\
\hline $\mathrm{OM}^{6}$ & 69.8 & 69.5 & 69.0 & 69.5 & \pm 1.6 & 0.4829 & 0.9952 & 0.4140 \\
\hline $\mathrm{CP}^{7}$ & 77.1 & 77.0 & 76.1 & 74.4 & \pm 2.6 & 0.2539 & 0.0638 & 0.7096 \\
\hline $\mathrm{EE}^{8}$ & 70.9 & 75.3 & 69.4 & 70.2 & \pm 6.5 & 0.8013 & 0.1334 & 0.2459 \\
\hline $\mathrm{NDF}^{3,9}$ & 42.3 & 46.1 & 43.6 & 39.6 & \pm 4.5 & 0.6604 & 0.0077 & 0.6699 \\
\hline NDFap $^{10}$ & 40.5 & 46.3 & 42.8 & 43.7 & \pm 4.8 & 0.0688 & 0.2826 & 0.3163 \\
\hline $\mathrm{TC}^{11}$ & 67.8 & 67.4 & 67.1 & 68.3 & \pm 1.7 & 0.7236 & 0.2874 & 0.3528 \\
\hline NFCap $^{12}$ & 91.9 & 88.7 & 89.1 & 87.8 & \pm 2.1 & 0.0016 & 0.4273 & 0.3903 \\
\hline $\mathrm{TDN}^{4,13}$ & 63.4 & 65.2 & 61.0 & 60.1 & \pm 3.5 & 0.4901 & 0.0213 & 0.2175 \\
\hline
\end{tabular}

${ }^{1} \mathrm{C}$ vs $\mathrm{CaO}$ : control (natural sugar cane) vs calcium oxide $(\mathrm{CaO})$ treated sugar cane; $\mathrm{L}$ and Q: linear and quadratic effects of $\mathrm{CaO}$ doses on sugar cane. ${ }^{2} \hat{Y}=68.2931-1.47549 \mathrm{X}\left(\mathrm{r}^{2}=0.9793\right) .{ }^{3} \hat{Y}=49.7375-4.44526 \mathrm{X}\left(\mathrm{r}^{2}=0.9796\right) .{ }^{4} \hat{Y}=66.7807-2.96250 \mathrm{X}\left(\mathrm{r}^{2}=0.7955\right)$.

${ }^{5}$ Dry matter. ${ }^{6}$ Organic matter. ${ }^{7}$ Crude protein. ${ }^{8}$ Ether extract. ${ }^{9}$ Neutral detergent fiber. ${ }^{10}$ Neutral detergent fiber with corrections for ash and protein.

${ }^{11}$ Total carbohydrate. ${ }^{12}$ Non-fibrous carbohydrate with corrections for ash and protein. ${ }^{13}$ Total digestible nutrients. 
lambs fed sugar cane treated with three $\mathrm{CaO}$ doses $(0,0.5$ and $1 \%$ ) and two storage periods ( 0 and $24 \mathrm{~h}$ ), Pontes (2007) observed a linear decrease in the DM digestibility values, which is the same as the results observed in the present study. The DM digestibility decrease was also reported by Moraes (2006) when feeding the animals natural sugar cane treated or not treated with $1 \%$ of $\mathrm{CaO}$; the apparent digestibility values of 62.8 and $56.9 \%$, respectively, were reported for diets containing sugar cane without and with $\mathrm{CaO}$. The author also evaluated the ruminal apparent digestibility of these diets and did not observe any effect on the nutrient digestibility with $\mathrm{CaO}$ added to the sugar cane.

Therefore, the decrease in the DM and NDF digestibility observed in the present study may be, in part, supported by the statements of Moraes (2006) and Pontes (2007), who reported that the decreased digestibility found in diets containing sugar cane treated with $\mathrm{CaO}$ may be associated with high $\mathrm{pH}$ values. It is possible that the $\mathrm{pH}$ increase in the sugar cane treated with the $\mathrm{CaO}$ doses (Table 2) caused a deleterious effect on the ruminal microorganisms, leading to a reduction in digestibility. Another possible explanation is related to the increase in $\mathrm{DM}$ intake, in $\mathrm{g} / \mathrm{d}$ and $\% \mathrm{BW}$, which, as discussed previously, may have contributed to an increase in the feed passage rate, causing a decrease in the DM digestibility coefficients. It is important to notice, however, that the decrease in DM digestibility coefficients were 1.6, 3.4 and $5.1 \%$ for the diets containing sugar cane treated with 0.75 , 1.5 and $2.25 \%$ of $\mathrm{CaO}$, respectively, when compared to the diet containing natural sugar cane (no $\mathrm{CaO}$ addition). These values were modest when compared to those observed for the increase in intake, which increased by $20 \%$ for the largest dose of $\mathrm{CaO}$.

The $\mathrm{CaO}$ treatment of sugar cane evaluated in the present study contradicts the assumption made by Ezequiel et al. (2005), who said that when the roughage treatment with alkaline products affects the digestibility of the fibrous portions, it improves the use of the fiber present in the diet, leading to a greater availability of energy for microbial growth. The absence of a significant effect $(p>0.05)$ for most of the components and the reduction in the FDN digestibility coefficient with the addition of $\mathrm{CaO}$ to the sugar cane strongly suggest that the chemical treatment does not achieve its maximum efficiency in all situations. From the data available in the literature, it is likely that the higher alkalization power of the $\mathrm{NaOH}$ improves the efficiency of the effect on roughage treatment.

A more efficient $\mathrm{NaOH}$ action on the fibrous components of roughage may be observed in the studies of Ezequiel et al. (2005) and Pires et al. (2006). However, Nussio et al. (2003) argued that although it presents satisfactory results, $\mathrm{NaOH}$ use has been avoided because of the possible contamination of the environment, excessive sodium in the diet, feces and urine, and above all, because of the risks it presents to human health during its manipulation.

The absence of a positive effect from $\mathrm{CaO}$ use on fiber digestibility in sugar cane was also reported by Campos (2007), who evaluated a $0.6 \%$ addition of $\mathrm{CaO}$ to sugar cane combined with different levels of urea $(0,0.33,0.66$ and $0.99 \%$, as-fed basis), compared to natural sugar cane corrected with $1 \%$ urea, in lamb diets. The author observed a decrease in NDFap digestibility in the treatment with $0.6 \%$ of $\mathrm{CaO}$ and no urea and the absence of any effect of the $\mathrm{CaO}$ combined with the urea treatments; they found similar digestibility values among the treatments and with the natural sugar cane.

The estimates of the DM fecal excretion, the nutrient digestibility coefficients and the TDN content as a function of the days of total fecal collection are presented in Table 6 .

The evaluation of the days of total fecal collection (two and four days) on the estimates of the dry matter fecal excretion, the nutrient digestibility coefficients and the TDN content of the diets did not show a significant difference $(p>0.05)$ between the mean values of any of the variables evaluated, suggesting that two days of total collection are sufficient to accurately estimate the variables (Table 6). On experiments with lambs kept in a feedlot, the possibility of using two days of fecal collection instead of four makes it easier and quicker to obtain the estimates of the fecal excretion and the digestibility coefficients.

Table 6. Mean and coefficient of variation of fecal excretion of dry matter and digestibility of dry matter and nutrients estimated using two or four days of total collection in sheep

\begin{tabular}{|c|c|c|c|c|}
\hline \multirow{2}{*}{ Item } & \multicolumn{2}{|c|}{ Days of total collection } & \multirow{2}{*}{$\mathrm{SD}^{1}$} & \multirow{2}{*}{$\mathrm{SEM}^{2}$} \\
\hline & $2 \mathrm{~d}$ & $4 \mathrm{~d}$ & & \\
\hline $\operatorname{DMFEX}^{2}(\mathrm{~kg} / \mathrm{d})$ & $0.233^{\mathrm{a}}$ & $0.242^{\mathrm{a}}$ & \pm 5.3 & 0.01 \\
\hline \multicolumn{5}{|c|}{ Digestibility coefficients and TDN (\%) } \\
\hline $\mathrm{MS}^{3}$ & $67.6^{\mathrm{a}}$ & $66.6^{\mathrm{a}}$ & \pm 3.0 & 0.53 \\
\hline $\mathrm{MO}^{4}$ & $70.4^{\mathrm{a}}$ & $69.5^{\mathrm{a}}$ & \pm 2.8 & 0.49 \\
\hline $\mathrm{PB}^{5}$ & $76.9^{\mathrm{a}}$ & $76.1^{\mathrm{a}}$ & \pm 3.4 & 0.61 \\
\hline $\mathrm{EE}^{6}$ & $72.4^{\mathrm{a}}$ & $71.5^{\mathrm{a}}$ & \pm 7.3 & 1.30 \\
\hline $\mathrm{FDN}^{7}$ & $44.7^{\mathrm{a}}$ & $42.9^{\mathrm{a}}$ & \pm 6.7 & 1.19 \\
\hline FDNap $^{8}$ & $45.1^{\mathrm{a}}$ & $43.3^{\mathrm{a}}$ & \pm 6.9 & 1.21 \\
\hline $\mathrm{CT}^{9}$ & $68.7^{\mathrm{a}}$ & $67.7^{\mathrm{a}}$ & \pm 3.1 & 0.54 \\
\hline CNFap $^{10}$ & $89.7^{\mathrm{a}}$ & $89.4^{\mathrm{a}}$ & \pm 3.4 & 0.60 \\
\hline $\mathrm{NDT}^{11}$ & $63.7^{\mathrm{a}}$ & $62.6^{\mathrm{a}}$ & \pm 4.6 & 0.81 \\
\hline
\end{tabular}

\footnotetext{
${ }^{1}$ Standard deviation. ${ }^{2}$ Standard error of mean.

${ }^{3}$ Dry matter fecal excretion. ${ }^{4}$ Dry matter. ${ }^{5}$ Organic matter.

${ }^{6}$ Crude protein. ${ }^{7}$ Ether extract. ${ }^{8}$ Neutral detergent fiber.

${ }^{9}$ Neutral detergent fiber with corrections for ash and protein.

${ }^{10}$ Total carbohydrate.

${ }^{11}$ Non-fibrous carbohydrate with corrections for ash and protein

${ }^{12}$ Total digestible nutrients (TDN)
}

Means on the same line, followed by the same letters, do not differ at a 0.05 probability level on the $\mathrm{F}$ test. 
Moreover, the two-day collection reduces labor, saves time and reduces the stress caused by the use of bags and other procedures while handling the animals during the collection.

Comparing the digestibility coefficients of different forages (sugar cane, sugar cane silage, soybean silage, mombaça silage and Tifton-85 hay), obtained in three or five days of total fecal collection, Magalhães (2007) did not observe a difference for the collection periods, recommending the use of three days for a conventional bovine digestibility assay to obtain the nutrient digestibility estimates.

The observed results also agree with the ones reported by Barbosa (2005). The author compared the estimates for the digestibility coefficients obtained for one, two, and three days of total collection to the estimates obtained for four days of collection. In another evaluation of the same study, the author compared the estimates obtained for one, two, three, four and five days of total collection to the estimates obtained for six days of collection and concluded that the digestibility coefficients may be obtained from the total fecal collection from one to six days. The author stressed, however, that the precision improved with an increase in the number of collection days.

\section{CONCLUSIONS}

Diets containing sugar cane treated with up to $2.25 \%$ of calcium oxide for feeding lambs promote an increase in the intake of most nutrients. However, these diets decrease the dry matter and neutral detergent fiber digestibility coefficients and the total digestible nutrient content.

Even with the modest decrease observed in the dry matter and neutral detergent fiber digestibility coefficients and in the total digestible nutrient content, the intake of dry matter and neutral detergent fiber increased by approximately $20 \%$ and justify the use of calcium oxide in the chemical treatment of sugar cane destined to be used to feed lambs.

Two or four days of total fecal collection may be used to derive estimates of the dry matter fecal excretion and apparent digestibility in lambs.

\section{REFERENCES}

Amaral, R. C. 2007. Evaluation of chemical additives on losses and alimentary value of sugar cane silage for sheep. Piracicaba: Escola Superior de Agricultura "Luiz de Queiroz"/Universidade de São Paulo. p. 168.

Andrade, J. B., E. Ferrari Júnior, R. A. Possentini, F. F. Leinz, D. Bianchini and C. F. C. Rodrigues. 2001. Nutritive value of sugarcane silage treated with levels of sodium hydroxide and ground corn ears. Brazilian J. Agric. Res. 36:1265-1268.

Barbosa, A. M. 2005. Period of urine and feces collection for evaluation of creatinine excretion, microbial production and nutrients apparent digestibility in Nelore bovines. Viçosa: Universidade Federal de Viçosa.

Campos, M. M. 2007. Valor nutritivo da cana de açúcar adicionado ou não com óxido de cálcio com diferentes níveis de uréia em ovinos. p. 67. Dissertação (Mestrado em Ciência Animal) - Escola de Veterinária da Universidade Federal de minas Gerais, UFMG, Belo Horizonte.

Carvalho, G. G. P., A. J. V. Pires, C. M. Veloso, A. F. Magalhães, M. A. L. Freire, F. F. Silva, R. R. Silva and B. M. A. Carvalho. 2006. Nutritive value of sugarcane bagasse ammoniated with four urea doses. Brazilian J. Agric. Res. 41:125-132.

Casali, A. O., E. Detmann, Valadares Filho, J. C. Pereira, L. T. Henriques, S. G. Freitas and M. F. Paulino. 2008. Influence of incubation time and particles size on indigestible compounds contents in cattle feeds and feces obtained by in situ procedures. Braz. J. Anim. Sci. 37:335-342.

Cavali, J. 2006. Sugar cane ensiled with calcium oxide, elephantgrass or bacterial inoculant. Viçosa: Universidade Federal de Viçosa.

Costa, R. G., R. C. R. E. Queiroga and R. A. G. Pereira. 2009. Influence of feed on the production on quality of goat milk. Braz. J. Anim. Sci. 38:307-321.

Ezequiel, J. M. B., M. A. A. Queiroz, R. L. Galati, A. R. Mendes, E. M. O. Pereira, C. Faturi, V. F. Nascimento Filho and J. V. Feitosa. 2005. Effects of Sugar Cane Processing on Digestibility, Intake and Rate of Passage. Braz. J. Anim. Sci. 34:1704-1710.

Fernandes, A. R. M., A. A. M. Sampaio, W. Henrique, E. A. Oliveira, R. V. Oliveira and F. R. Leonel. 2009. Fatty acids composition and meat quality of Nellore and Canchim young bulls fed sugar cane-based diets with two concentrate levels. Braz. J. Anim. Sci. 38:328-337.

Hall, M. B. 2003. Challenges with non-fiber carbohydrate methods. J. Anim. Sci. 81:3226-3232.

IBGE (Instituto Brasileiro de Geografia e Estatística). 2008. Avaiable at: http://www.ibge.gov.br Acessed on : Apr. 24, 2009.

Landell, M. G. A., M. P. Campana, A. A. Rodrigues, G. M. da Cruz, L. A. R. Batista, P. Figueiredo, M. A. de Silva, M. A. P. Bidoia, R. Rossetto, A. L. M. Martins, P. B. Gallo, R. A. D. Kanthack, J. C. Cavichioli, A. C. M. de Vasconcelos and M. A. Xavier. 2002. A variedade IAC86-2480 como nova opção de cana-deaçúcar para fins forrageiros: Manejo de produção e uso na alimentação animal. Campinas: Instituto Agronômico - IAC, p. 38. (Boletim Técnico 193).

Licitra, G., T. M. Hernandez and P. J. Van Soest. 1996. Standardization of procedures for nitrogen fracionation of ruminant feeds. Anim. Feed Sci. Technol. 57:347-358.

Magalhães, K. A. 2007. Tabelas brasileiras de composição de alimentos, determinação e estimativa de valor energético dos alimentos para ruminantes. Viçosa: Universidade Federal de Viçosa. p. 263. Tese (Doutorado em Zootecnia). Universidade Federal de Viçosa, Viçosa.

Mertens, D. R. 2002. Gravimetric determination of amylasetreated neutral detergent fiber in feeds with refluxing in beakers or crucibles: collaborative study. J. AOAC Int. 85: 1217-1240.

Moraes, K. A. K de. 2006. Performance of beef heifers fed with 
sugar cane treated with calcium oxide and different concentrate levels. Viçosa: Universidade Federal de Viçosa, 2006.

NRC (National Research Council). 2001. Nutrient requirements of dairy cattle. 7 ed. Washington: National Academy Press. p. 381.

NRC (National Research Council). 2006. Nutrient requirements of small ruminants. 1 ed. Washington: National Academy Press. p. 362.

Nussio, L. G., P. Schimdt and A. F. Pedroso. 2003. Sugar cane silage. In: Simpósio de forragicultura e pastagens: temas em evidência - Sustentabilidade, 2003, Lavras. Anais... Lavras: Universidade Federal de Lavras, p. 49-74.

Oliveira, E. A., A. A. M. Sampaio, A. R. M. Fernandes, W. Wignez Henrique, R. V. Oliveira and G. M. Ribeiro. 2009. Performance and carcass traits of Nellore and Canchim young bulls finished in a feedlot system, receiving diets with sugarcane and two concentrate levels. Braz. J. Anim. Sci. 38:2465-2472.

Oliveira, M. D. S., A. T. Andrade, J. C. Barbosa, T. M. Silva, A. R. M. Fernandes, E. Caldeirão and A. Carabolante. 2007. Digestibility of sugarcane hidrolysed, in natura and ensilge for bovines. Brazilian Anim. Sci. 8:41-50.

Oliveira, M. D. S., M. A. A. Queiroz, E. Caldeirão, V. Bett and G. M. Ribeiro. 2002. Effect of sodium hidroxide treatment on in vitro digestibility of dry matter of sugarcane. Ars Veterinária, 18:167-173.

Pessoa, R. A. S., M. I. Leão, M. A. Ferreira, S. C. Valadares Filho, R. F. D. Valadares and A. C. Queiroz. 2009. Nitrogenous compounds balance and microbial protein production in crossbred heifers fed forage cactus, sugar cane bagasse and urea associated to different supplements. Braz. J. Anim. Sci. 38:941-947.

Pinto, A. P., J. J. S. Abrahão, J. A. Marques, W. G. Nascimento, D. Perotto and S. M. B. Lugão. 2010. Performance and carcass characteristics of crossbred young bulls finished in a feedlot on diets with sorghum silage substituted by sugar cane. Braz. J. Anim. Sci. 39:198-203.
Pinto, A. P., W. G. Nascimento, J. J. S. Abrahão, D. Perotto, J. L. Moletta and S. M. B. Lugão. 2009. Digestibility, intake, performance and carcass characteristics of young crossbred bulls in feedlot with sugar cane or sorghum silage. Braz. J. Anim. Sci. 38:2258-2263.

Pires, A. J. V., R. Garcia, S. C. Valadares Filho, O. G. Pereira, P. R. Cecon, F. F. Silva, P. A. Silva and C. M. Veloso. 2004. Diets with of sugarcane bagasse treated with anhydrous ammonia and/or sodium sulfate fed heifers. Braz. J. Anim. Sci. 33:10781085 .

Pires, A. J. V., R. A. Reis, G. G. P. Carvalho, G. R. Siqueira and T. F. Bernardes. 2006. Sugarcane bagasse treated sodium hydroxide. Braz. J. Anim. Sci. 35:953-957.

Pontes, R. A. M. 2007. Sugar cane in natura or ensiled with calcium oxide and urea in ovine diets. Viçosa: Universidade Federal de Viçosa.

Prado, I. N. and F. B. Moreira. 2002. Suplementação de pastagem de gado e alimentos para animais utilizados em bovinos. EDUEM, UEM. Maringá: Universidade Estadual de Maringá.p. 162.

Ribeiro Jr, J. I. 2001. Statistical analysis in SAEG (System for statistical analysis). Viçosa, MG: UFV.

SAS. 1999. Statistical analysis system, user's guide statistics. 8th Ed. SAS Institute Inc., Cary, USA, p. 956.

Silva, D. J. and A. C. Queiroz. 2002. Análise de alimentos: métodos químicos e biológicos. Viçosa: Universidade Federal de Viçosa.

Sniffen, C. J., J. D. O'Connor, P. J. Van Soest, D. G. Fox and J. B. Russell. 1992. A net carbohydrate and protein system for evaluating cattle diets: carbohydrate and protein availability. J. Anim. Sci. 70:3562-3577.

Souza, A. L., R. Garcia, O. G. Pereira, P. R. Cecon, A. V. Pires and D. R. S. Loures. 2002. Valor nutritivo da casca de café tratada com amônia anidra. Revista Ceres, v.49, p. 669-681.

Weiss, W. P. 1999. Energy prediction equations for ruminant feeds. In: Cornell nutrition conference for feed manufacturers, 61., 1999, Ithaca. Proceedings... Ithaca: Cornell University. p. 176185. 